\title{
Utilization of Crop Residue for Power Generation: The Case of Ukraine
}

\author{
Yongzhong Jiang ${ }^{1,2}$, Valerii Havrysh ${ }^{3}{ }^{(D)}$, Oleksandr Klymchuk ${ }^{4}$, Vitalii Nitsenko ${ }^{5}$, \\ Tomas Balezentis ${ }^{6, *(D)}$ and Dalia Streimikiene ${ }^{6}$ (D) \\ 1 College of Management Science, Chengdu University of Technology, 1 ErXianQiaoDongSan Rd, \\ Chengdu 610059, China; jiangyongzhong08@mail.cdut.edu.cn \\ 2 Department of Economics, University of Kansas, 1460 Jayhawk Blvd., 415 Snow Hall, Lawrence, \\ KS 66045, USA \\ 3 Department of Tractors and Agricultural Machinery, Operating and Maintenance, Mykolayiv National \\ Agrarian University, Mykolayiv 54020, Ukraine; havryshvi@mnau.edu.ua \\ 4 Department of Administrative Management and Alternative Sources of Energy, Vinnytsia National Agrarian \\ University, Vinnytsia 21000, Ukraine; klimchuk@vsau.vin.ua \\ 5 Department of Accounting and Taxation, Interregional Academy of Personnel Management, \\ Higher education institution, Private Joint-Stock Company, Kyiv 03039, Ukraine; \\ vitaliinitsenko@onu.edu.ua \\ 6 Division of Farm and Enterprise Economics, Lithuanian Institute of Agrarian Economics, Vilnius 01113, \\ Lithuania; dalia@mail.lei.lt \\ * Correspondence: tomas@laei.lt
}

Received: 26 October 2019; Accepted: 4 December 2019; Published: 8 December 2019

\begin{abstract}
Renewable energy is expected to play a significant role in power generation. The European Union, the USA, China, and others, are striving to limit the use of energy crop for energy production and to increase the use of crop residue both on the field and for energy generation processes. Therefore, crop residue may become a major energy source, with Ukraine following this course. Currently in Ukraine, renewable power generation does not exceed $10 \%$ of total electricity production. Despite a highly developed agriculture sector, there are only a small number of biomass power plants which burn crop residues. To identify possibilities for renewable power generation, the quantity of crop residues, their energy potential, and potential electricity generation were appraised. Cluster analysis was used to identify regions with the highest electricity consumption and crop residue energy potential. The major crops (wheat, barley, rapeseed, sunflower, and soybean) were considered in this study. A national production of crop residue for energy production of 48.66 million tons was estimated for 2018. The availability of crop residues was analyzed taking into account the harvest, residue-to-crop ratio, and residue removal rate. The crop residue energy potential of Ukraine has been estimated at 774.46 PJ. Power generation technologies have been analyzed. This study clearly shows that crop residue may generate between 27 and 108 billion kWh of power. We have selected preferable regions for setting up crop residue power plants. The results may be useful for the development of energy policy and helpful for investors in considering power generation projects.
\end{abstract}

Keywords: cluster analysis; energy potential; biomass availability; electricity consumption; residue-to-crop ratio

\section{Introduction}

Ukrainian power plants annually generate more than 150 billion $\mathrm{kWh}$. Approximately $37.8 \%$ of electricity is produced from fossil fuels (coal and natural gas) [1]. In 2018, Ukrainian thermal power plants consumed 26.22 million tons of coal [2]. To reduce greenhouse gas (GHG) emissions 
and improve energy security, renewable power generation needs to be developed. Ukraine currently operates 10 biomass and 33 biogas power plants [1].

Since 2011, Ukraine has been a member of the Energy Community [3]. Therefore, the country is obliged to implement European Union directives concerning renewable energy, including for biomass utilization. Despite the fact that Ukraine's electricity consumption is decreasing, renewable power generation is almost stable (Figure 1). Its share of the country's power generation ranged from $5.49 \%$ in 2009 to $9.54 \%$ in 2018 .

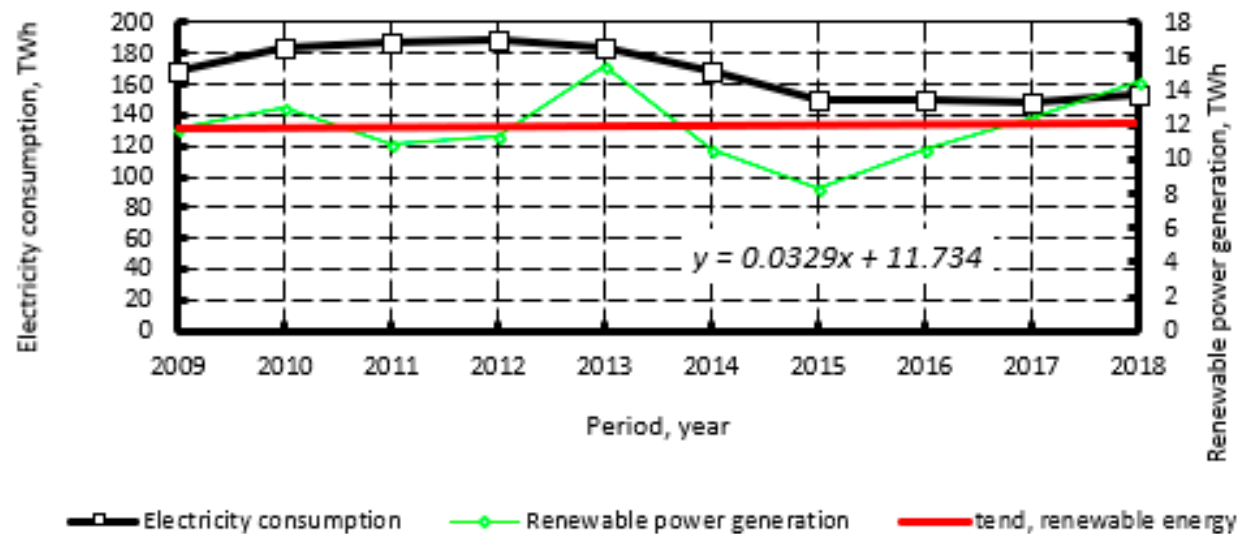

Figure 1. Electricity consumption and renewable power generation (adapted from references [1,4-6]).

Large scale biofuel production from edible crops (corn, rapeseed, soybean, sugar beet) may have a negative impact on food supply and its prices, soil erosion, and biodiversity [7]. Indeed, agricultural crop residue may be an environmentally and food friendly source of renewable energy [8]. European Union policy is currently aimed at reducing the use of crops and increasing the use of agricultural residue as feedstock for biofuel production [9]. Therefore, the availability of biomass for energy and material production is an important question for the development of energy policy. There are a number of studies discussing the agricultural crop residue energy potential available in the world, including at separate country and regional levels. Bioenergy is in the spotlight for researchers.

Most earlier studies were focused on energy potential, conversion technologies, or existing problems (environmental, financial, and political) of bioenergy $[10,11]$. Gao et al. studied the spatial distribution and total biomass potential for energy production in China [12]. Bentsen et al. provided estimates of agricultural residue production on a global scale. Its geographic variation in 227 countries was revealed [13]. Ren et al. reviewed wheat straw utilization issues on a global scale and a national level (China). They analyzed utilization technologies and their commercialization, benefits, and barriers. Their study revealed that straw utilization technologies are currently becoming profitable and straw utilization results in fossil fuels saving and reducing hazardous emissions, especially greenhouse gases [14]. Some studies assessed the bioenergy potential at local levels [15]. The utilization of biomass residue for power generation was studied in some countries. The availability of biomass and its potential disadvantages were revealed $[16,17]$. In addition to agricultural waste, agrifood industry waste was the subject of research for the production of energy resources [18,19].

There are a number of studies devoted to the analysis of power generation from solid biomass in Ukraine. State-of-the-art of electricity production and choosing steam turbines for combustion based biomass combined heat and power (CHP) plants were carried out by Geletukha et al. [20]. However, a combustion based technology is only one of the main existing technologies. Fedorchenko [21] and Melnychenko [22] used cluster analysis to evaluate the energy potential in the regions of Ukraine. In addition, Fedorchenko [21] focused on energy crops (corn and rapeseed) for biofuel production and Melnychenko [22] analyzed field-based crop residues. However, a number of the other crops (soybean, rapeseed, etc.) were left out along with any discussion on process-based crop residues and the residue removal rate. Moreover, the aforementioned studies only focused on a single region of the country. 
Zvorykin et al. [23] studied the status and future developments of electricity generation in Ukraine. The development of power generation and existing barriers were studied too [24]. To evaluate the efficiency of alternative energy resources, mathematical models have been widely used [25,26].

All in all, the previous studies did not examine the potential for power generation from crop residue in Ukraine in a systematic manner. Specifically, the following limitations apply to the earlier research: only extant major power generation technology was considered (i.e., direct biomass combustion); availability of major crop residues, including field-based resources, was ignored (e.g., sunflower stalk and soybean straw); also, process-based resources were neglected (e.g., sunflower husk). Therefore, further comprehensive analysis is needed to estimate the available crop residues (based on current agricultural practice) and power generation technologies. In order to assess the potential of agricultural crop residue for power generation, this study focuses on: (i) the quantity of agricultural crop residue; (ii) their geographical locations; (iii) analysis of technologies for biomass energy transformation into electricity; (iv) potential power generation.

\section{Literature Review on Biomass Energy}

There are four main pathways for crop residue utilization (Figure 2). Straw burning is still a common practice in some developing countries. A proportion of crop residue is stored at landfills. An alternative is to return crop residue to fields as a fertilizer and to prevent soil erosion. Straw is used for livestock bedding and housing too [14].

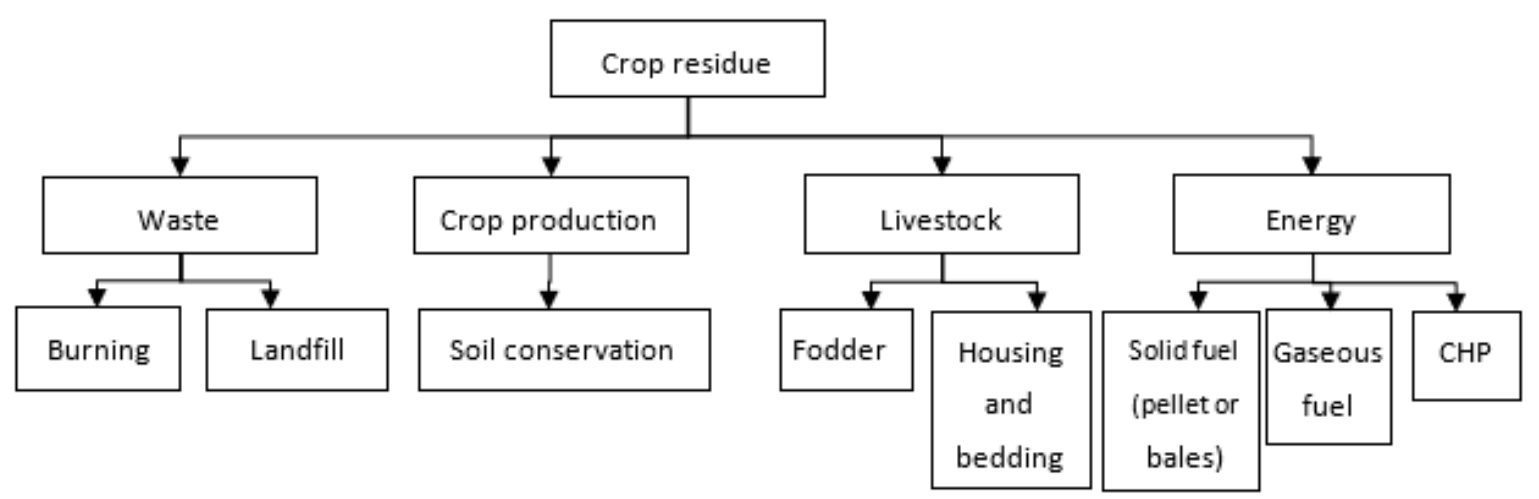

Figure 2. Crop residue utilization.

Agricultural crop residue can be converted into electricity. Thermochemical, methanation, and fermentation processes can be used to obtain fuels [27-29]. The thermochemical process is the most common. The fuels can be used in boilers (combustion based crop residue power plants), internal combustion engines (ICE), gas turbine engines, and fuel cells. Biomass co-firing with fossil fuels is an alternative to direct biomass burning. It has a number of advantages over direct biomass power plants: minimal investment costs and higher efficiency [16] (Figure 3).

Crop biomass can have a high mineral content. That is why its combustion results in combustion problems [3]. To improve the quality of crop residue, different technologies are used, including gasification, pyrolysis, and liquefaction.

Being able to run at full load without unplanned outages and governmental subsidies would indicate the economic viability of straw utilization projects [30]. The above technologies have different efficiency and maturity levels. 


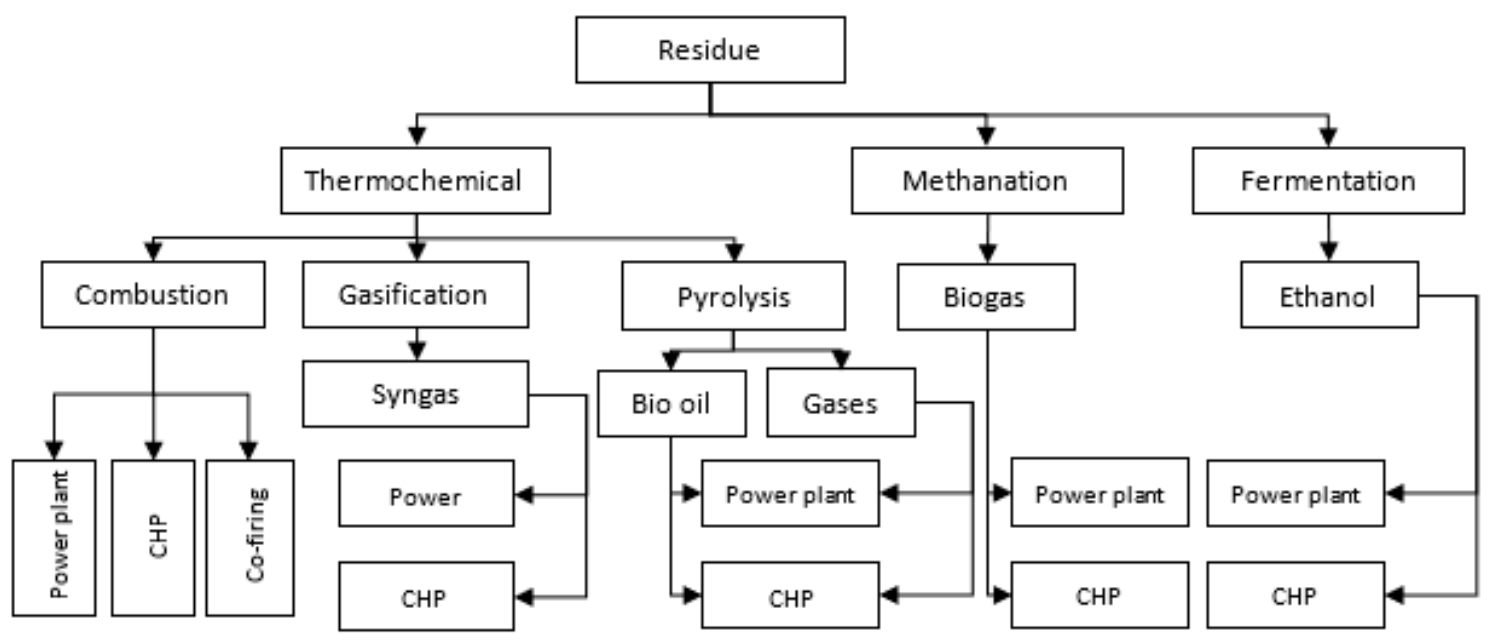

Figure 3. Technologies for power generation from biomass.

\subsection{Combustion-Based Biomass Generation Plants}

The electric efficiency of straw-based power and CHP plants depend on their capacity (Figure 4) [31,32] and ranges from $18 \%$ to $32 \%$. This technology is widespread.

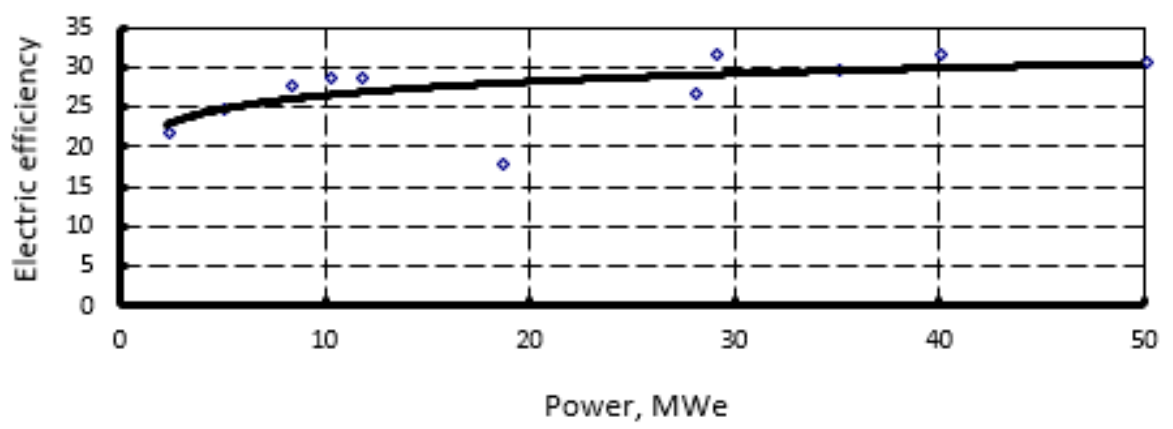

Figure 4. Electric efficiency versus power (developed by the authors, adapted from references [31,32]).

\subsection{Gasification- and Pyrolysis-Based Biomass Power Generation Plants}

The atmospheric oxidation and pyrolysis gasification technologies are mature for household supply. However, a number of technological problems and high investment costs hinder their commercial development [33]. Their electric efficiency ranges from 10\% to 33\% [33-36]. Their energy conversion factor ranges from 0.5 to 0.8 [34,37]. According to experts' recommendations, gasification based crop residue technologies are preferable if their electrical power production is less than $2 \mathrm{MW}$ [38]. Therefore, this technology is not widespread and still in the early commercial stages. Pyrolysis technology for power generation is currently not at a mature commercial stage [39].

The Polohy oil extraction plant PJSC (Zaporizhya, Ukraine) has experience in utilizing residue (sunflower husk) gasification technology. However, this technology proved to be economically infeasible. Therefore, the plant abandoned this technology and currently uses direct burning of biomass.

\subsection{Biogas-Based Power Generation Plants}

Internal combustion engine (ICE) generators are more efficient than steam turbine generators. However, ICE generator need liquid or gaseous fuels (biogas, syngas, etc.), whereas steam turbine power plants can use all types of fuels. ICE generators' electrical efficiency reaches 50\% [40-42], whereas combustion based biomass steam turbine power plants have an efficiency of under 35\% [31,32]. Therefore, it is appropriate to study biogas production. Straw may be used as substrate for biogas production. Cereal straw is considered to be a promising feedstock for biogas production in the 
European Union [27]. The methane yield ranges from 242 to $324 \mathrm{~m}^{3} / \mathrm{t}$ [43]. Sukhesh, M. J., and Rao, P. V. summarized the following information: a yield of 125 to $380 \mathrm{~m}^{3} / \mathrm{t}$ for wheat straw, and a yield of -165 to $383 \mathrm{~m}^{3} / \mathrm{t}$ for corn stalk [44]. Straw has a high methane yield. However, straw is rarely used for biogas production due to the fact that it requires pre-treatment.

The energy conversion factor for biogas production varies from 0.38 to 0.88 , while direct burning (conversion into heat) provides the opportunity to reach an efficiency of up to 0.9 .

There have been demonstration projects in some countries such as Germany, China, and France [45]. Since 2005, the Chinese government has supported straw biogas plants [46]. Some of these demonstration projects are presented in Table 1.

Table 1. Straw biogas plants.

\begin{tabular}{|c|c|c|c|c|c|}
\hline Country & Location, Year & $\begin{array}{c}\text { Feedstock, } \\
\text { Thousand t/y }\end{array}$ & $\begin{array}{l}\text { Output, MW } \\
(\mathrm{GWh} / \mathrm{y})\end{array}$ & $\begin{array}{l}\text { Investment, } \\
\text { Million EUR }\end{array}$ & Reference \\
\hline Bulgaria & $\begin{array}{l}\text { Chernozemen, } \\
2013\end{array}$ & $\begin{array}{l}\text { cow slurry, } \\
\text { maize silage } \\
\text { and straw, } 50\end{array}$ & $1.5 \mathrm{MWe}$ & * & [47] \\
\hline Philippines & Laguna, 2019 & Rice straw & 1.2 MWe & USD6.7 million & {$[48]$} \\
\hline Germany & $\begin{array}{c}\text { Schwedt/Oder } \\
\text { (Verbio AG), } \\
2015\end{array}$ & Mono straw, 40 & $\begin{array}{c}\text { 16.5 MW (140 } \\
\text { GWh of } \\
\text { methane) }\end{array}$ & 25 & [49] \\
\hline China & Inner Mongolia & Straw, 55 & $108 \mathrm{GWh}$ & USD50 million & {$[30]$} \\
\hline India & $\begin{array}{c}\text { Fazilka, Punjab, } \\
2016\end{array}$ & 12 & $\begin{array}{c}1.0 \mathrm{MWe} \\
\left(12,000 \mathrm{~m}^{3} / \text { day }\right. \\
\text { of biogas })\end{array}$ & * & [50] \\
\hline
\end{tabular}

${ }^{*}$ Data is not available.

To convert biogas into electricity gas turbine engines, fuel cells, spark-ignition engines, and dual-fuel engines can be used. Internal combustion engines are currently widely used to convert biogas into electricity. In fact, in the European Union, biogas plants use spark-ignition engines $(50 \%)$, and dual-fuel internal combustion engines $(50 \%)$. Fuel cells and gas turbine engines are rarely used. The electrical efficiency of ICE is in a range between $34 \%$ and $48.7 \%$ (the capacity ranges from $100 \mathrm{~kW}$ to $\mathrm{kW})[40,41]$.

There are technologies to enhance the above indicator. These are turbo-compound, electric turbo-compound, thermoelectric generator, and organic Rankine cycle (ORC) [42,51]. However, ORC is the most promising technology [52]. It can increase the obtainable power by $5 \%$ to $19 \%[40,42,51]$. This means that the total potential power generation efficiency ranges from $12.9 \%$ to $50.2 \%$.

In 2015, the total biogas production in Ukraine exceeded 600 TJ [53]. Installed electric capacity of biogas plants is increasing. The electrical production capacity rose by up to $70 \mathrm{MW}$ [54]. Domestic and foreign practices related to biogas technology stimulate Ukrainian businesses to employ it further. Finish and German investors plan to build straw biogas plants in the Khmelnytsky and Vinnitsa regions [55].

\subsection{Ethanol Based Crop Residue Power Generation Plants}

Crop residue including straw can be converted into ethanol. Commercial projects have been realized in some countries such as Italy, Brazil, the USA, etc. [56]. Some examples of these plants are presented in Table 2. 
Table 2. Straw ethanol plants.

\begin{tabular}{|c|c|c|c|c|c|}
\hline Country & Location & $\begin{array}{l}\text { Feedstock, } \\
\text { Thousand } \\
\text { t/y }\end{array}$ & $\begin{array}{c}\text { Output } \\
\text { Ethanol, } \\
\text { Thousand } t / y\end{array}$ & $\begin{array}{l}\text { Investment, } \\
\text { Million EUR }\end{array}$ & Reference \\
\hline Finland & Kouvola, Myllykoski & 330 & 72 & 100 & [57] \\
\hline Italy & Crescentino, 2013 & 200 & 40 & 150 & [58] \\
\hline India & Kashipur, 2016 & & 10 t/day & * & [59] \\
\hline Brazil & $\begin{array}{l}\text { GranBio Cellulosic } \\
\text { Ethanol Production } \\
\text { Project, Alagoas }\end{array}$ & $\begin{array}{l}\text { (straw and } \\
\text { sugarcane } \\
\text { bagasse) }\end{array}$ & 82 & USD265 mln & {$[60]$} \\
\hline USA & $\begin{array}{l}\text { Canergy, LLC, Imperial } \\
\text { Valley's, California, 2013, } \\
\text { cane straw }\end{array}$ & & 94.7 & * & [52] \\
\hline USA & $\begin{array}{c}\text { Emmetsburg, Iowa, } 2014 \\
\text { Poet-DSM Advanced } \\
\text { Biofuels LLC }\end{array}$ & $\begin{array}{l}285 \\
\text { corn stover } \\
\text { and cob }\end{array}$ & 75.76 & USD275 mln & [56] \\
\hline Germany & Straubing, 2012 & $\begin{array}{l}4.5 \text { (Wheat } \\
\text { straw) }\end{array}$ & 1 & EUR28 mln & [61] \\
\hline Germany & Zörbig, 2010 & $\begin{array}{l}270 \text { (rye, } \\
\text { triticale and } \\
\text { wheat) }\end{array}$ & 60 & * & [62] \\
\hline China & $\begin{array}{l}\text { Longlive Bio-technology } \\
\text { Co. Ltd, Shandong }\end{array}$ & 400 & 60 & USD169 $\mathrm{mln}$ & [63] \\
\hline
\end{tabular}

For straw, the ethanol energy conversion factor ranges from 0.24 to 0.32 . Ethanol can be used for power generation in ICE or fuel cells. The efficiency of ICE can reach $40 \%$. The same value for fuel cells is up to $50 \%$ [33-36]. Due to relatively high production costs, it is fuel cells can be used for vehicle fuel, but are unprofitable for power generation.

\section{Materials and Methods}

\subsection{Data Collection}

The data for analysis was collected from the State Statistical Service of Ukraine. They included information about crop production, electricity generation, and energy consumption. The data of crop and residue production was presented in tons. Energy potential was expressed in PJ $\left(1 \mathrm{PJ}=10^{15}\right.$ $\mathrm{J}=0.6$ tons of oil equivalent) and power generation is presented in $\mathrm{kWh}$.

\subsection{Available Crop Residues}

Crop yields used in this study were estimated for an 11-year period (from 2007 to 2018) based on official statistical reports. Residue quantity was calculated based on the weight of harvested crop and Residue to Crop Ratio ( $R C R)$. Six major crops were included in this study: wheat, barley, corn, sunflower, rapeseed, and soybean. Residue production was calculated as

$$
M_{R}=\sum_{i=1}^{6}\left(M o_{i} \times R C R_{i}\right), \mathrm{t},
$$

where $M o_{i}$ is the harvest weight of $i^{\text {th }}$ crop, $\mathrm{t}, R C P_{i}$ is the Residue to Crop Ratio of $i^{\text {th }}$ crop; $i$ is the crop number. 
If crop yields are available in Statistical Yearbooks, that information about residue yields is limited. To estimate quantity of the agricultural crop residue, the residue-to-crop ratio should be used. According to reports, there can be a wide variation of this ratio. This information from a number of studies was summarized by Scarlat et al. [64], Bentsen et al. [13], Cardoen et al. [65], and Geletukha et al. [66]. The residue-to-crop ratios are in a wide range: wheat is from 0.8 to 1.8 ; barley is from 0.9 to 1.8 ; corn is from 0.8 to 2 ; sunflower is from 1 to 3 ; rapeseed is from 1.1 to 1.7 ; soybean is from 1.4 to 3.4. In this study, we assumed the average values for conditions of Ukraine: 1.275 for wheat at; 1.175 for barley; 1.375 for corn; 1.775 for sunflower; 1.4 for rapeseed-; 1.82 for soybean-.

The residue removal rate (for field-based residue) depends on a number of factors. According to the data reported, it ranges from $15 \%$ to $82 \%$ [64,66-69]. For Ukraine, general recommendations on the share of crop residue for bioenergy have been developed. The removal rate for agricultural crop residue (from the theoretical potential harvest) was taken from different research and used for our calculations: $30 \%$ for wheat and barley; $40 \%$ for corn, rapeseed, sunflower, and soybean- [66]. Most of the residue (except of sunflower husk) is field-based (crop residue).

\subsection{Energy and Power Generation Potential}

Moreover, sunflower husk utilization was studied. Energy potential was calculated by the following formula

$$
\mathrm{EP}=\sum_{i=1}^{6}\left(M o_{i} \times R C R_{i} \times L H V r_{i}\right), P J,
$$

where $L H V r_{i}$ is the lower heating value of $i^{\text {th }}$ crop residue, MJ $/ \mathrm{kg}$.

To convert energy potential into potential power generation, we multiplied the electricity efficiency of a power plant by the conversion factor that equals $1 / 3.6 \mathrm{kWh} / \mathrm{MJ}$. Therefore, potential power generation was calculated as

$$
P P G=\frac{E P}{3.6} \times \eta_{e}, \text { billion } \mathrm{kWh},
$$

where $E P$ is the energy potential of biomass, PJ; $\eta_{\mathrm{e}}$ is the electricity efficiency of power generation.

The energy conversion factor (residue to biogas, syngas, ethanol, etc.) is equal to

$$
\mathrm{ECF}=\frac{V_{D F} \times L H V_{D F}}{L H V_{R}}
$$

where $V_{D F}$ is the volume of derived fuel (ethanol, biomethane, etc.) from crop residue, $\mathrm{m}^{3} / \mathrm{kg}$; $L H V_{D F}$ is the lower heating value of the derived fuel, $\mathrm{MJ} / \mathrm{m}^{3} ; L H V_{R}$ is the lower heating value of crop residue, $\mathrm{MJ} / \mathrm{kg}$.

\subsection{Data Analysis}

The general data processing is as follows: assessment of the selected crop harvest; finding the residue-to-crop ratios; determining the quantity of the residue; calculation of energy potential and power generation potential; cluster analysis of crop production, residue production and electricity consumption. To determine groups of regions, taxonomic analysis with Ward's hierarchical clustering method was applied.

The cluster analysis was carried out using Statistica software. The 24 regions of Ukraine were grouped into clusters. Descriptive statistics of energy potential and crop production for each cluster were calculated. 


\section{Results}

\subsection{Electricity Consumption}

Firstly, electricity consumption across the regions was analyzed. A cluster analysis was carried out by using the statistical data [4]. It resulted in five clusters (Figure 5). Each cluster includes between 1 and 15 regions (Table 3). For better visualization, the above-mentioned clusters for electricity consumption are plotted on a map of Ukraine (Figure 6).

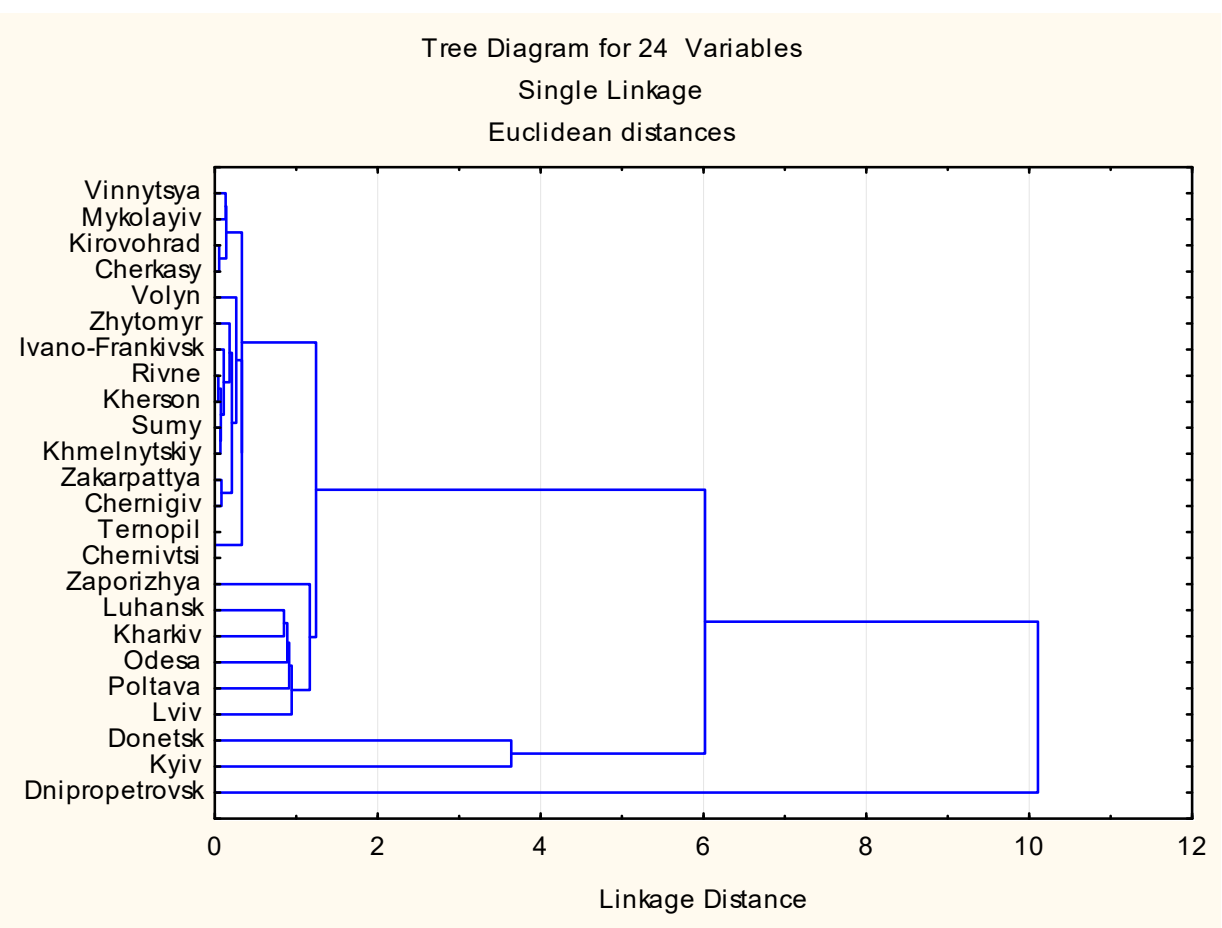

Figure 5. Dendrogram of relative electricity consumption.

Table 3. Clusters of electricity consumption.

\begin{tabular}{cccc}
\hline $\begin{array}{c}\text { Cluster } \\
\text { Number }\end{array}$ & Region (s) & $\begin{array}{c}\text { Relative Consumption } \\
\text { per Cluster, } \% \text { of } \\
\text { National Value }\end{array}$ & $\begin{array}{c}\text { Average per } \\
\text { Region, } \%\end{array}$ \\
\hline I & Dnipropetrovsk & 20.616 & 20.616 \\
\hline II & Donetsk & 13.469 & 13.469 \\
\hline III & Kyiv & 10.895 & 10.895 \\
\hline IV & $\begin{array}{c}\text { Lviv, Poltava, Odesa, Kharkiv, } \\
\text { Zaporizhya, and Luhansk }\end{array}$ & 29.459 \\
\hline & $\begin{array}{c}\text { Chernivtsi, Ternopil, Chernigiv, } \\
\text { Zakarpattya, Khmelnytskiy, Sumy, } \\
\text { Kherson, Rivne, Ivano-Frankivsk, } \\
\text { Zhytomyr, Volyn, Cherkasy, } \\
\text { Kirovohrad, Mykolayiv, Vinnytsya }\end{array}$ & 25.563 & 1.704 \\
\hline Total & - & 100 & \\
\hline
\end{tabular}




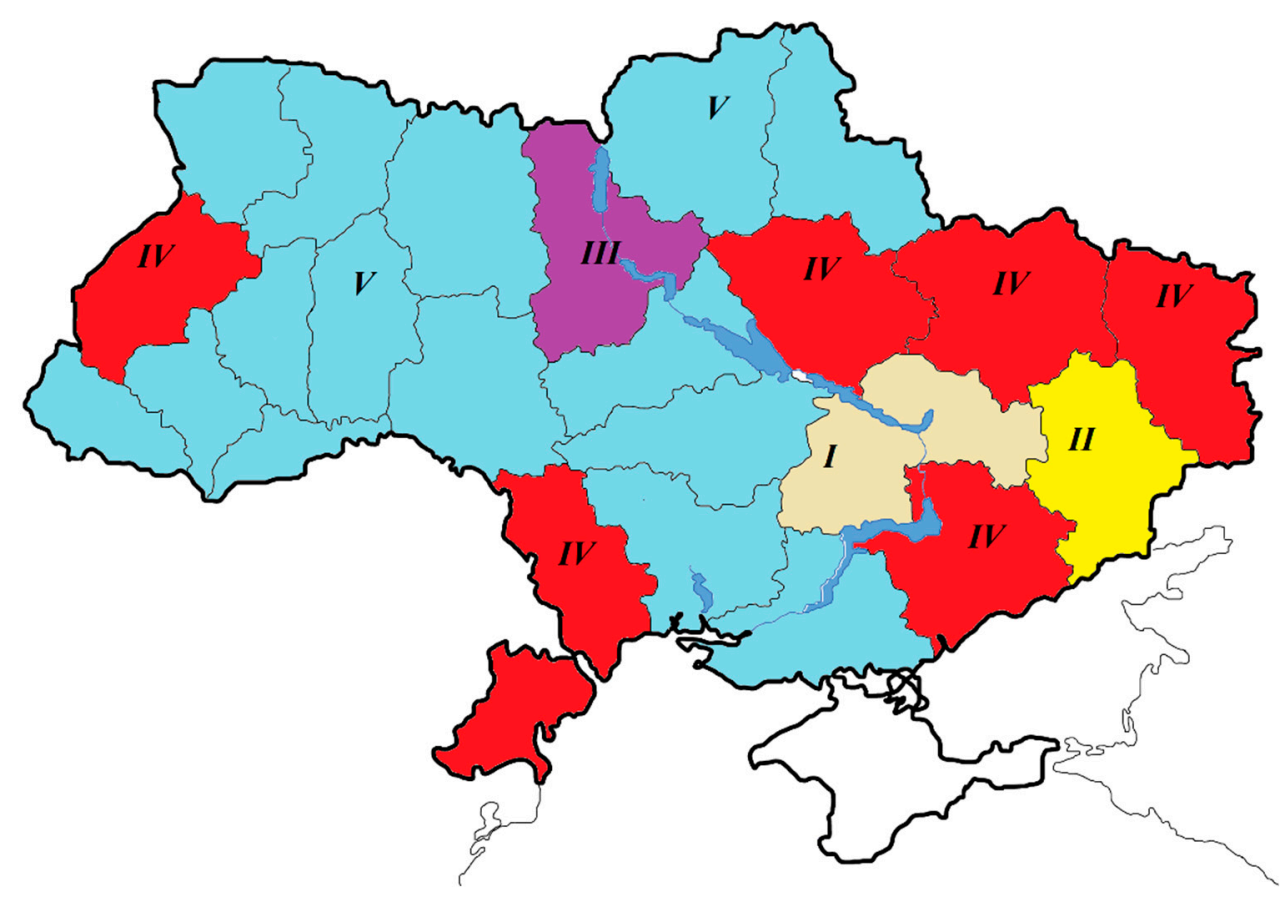

Figure 6. Visual presentation of the clusters for electricity consumption.

The largest consumers of electricity are the Dnipropetrovsk, Donetsk, and Kyiv regions. They used more than $44 \%$ of the total national electricity production. It is the result of highly developed industry.

\subsection{Crop Residue Availability for Power Generation}

Agricultural crop residue can be divided into two groups: field and processed. The field residues are straw, stalks, stubble, seed pods, etc. The processed residue from the crop is sunflower husk. In this paper, six crops were selected (Figure 7). Their yields, areas, and properties were studied.

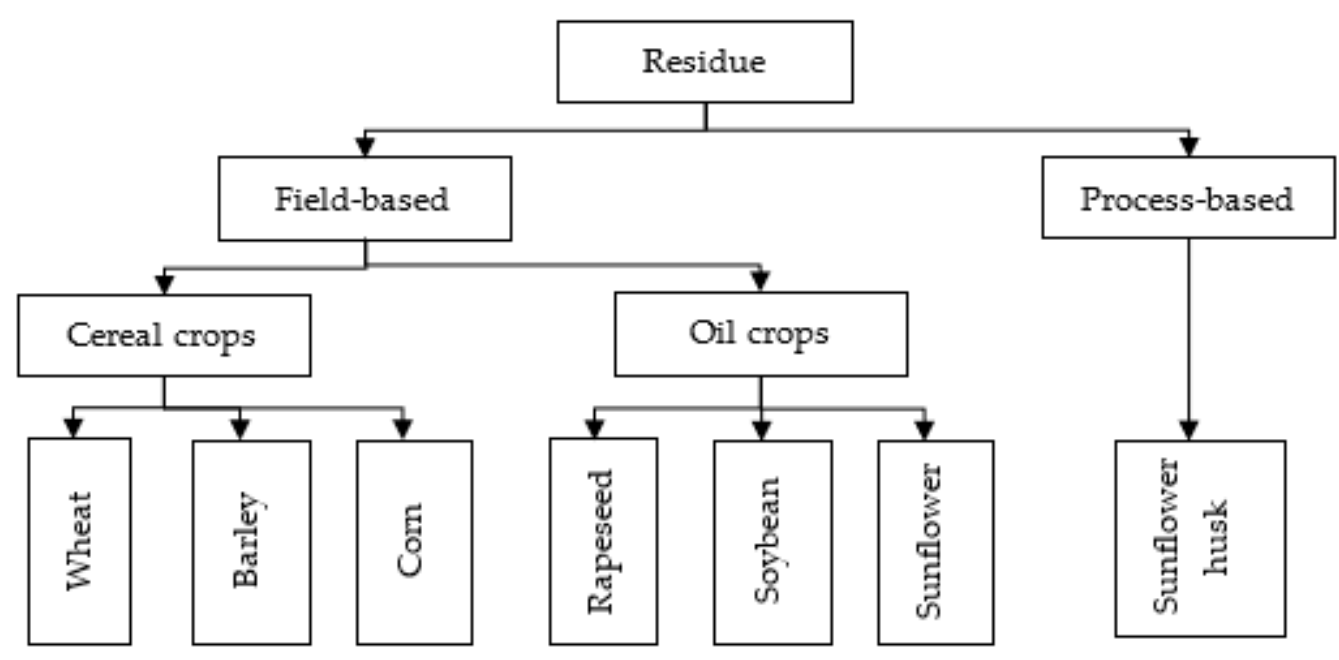

Figure 7. Selected crops residue.

The total area of arable land was 26,951 thousand ha in 2010. By 2018 its area had increased 27,699 to thousand ha. Since 2010, the share of the above crops has increased from $75.02 \%$ to $81.25 \%$ (Figure 8). 

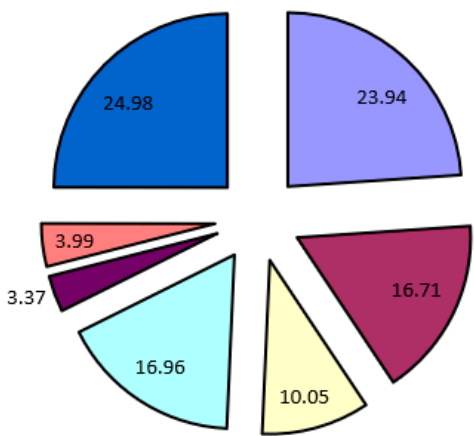

$\square$ wheat $\quad \square$ barley

口corn

口sunflower

口others

2010
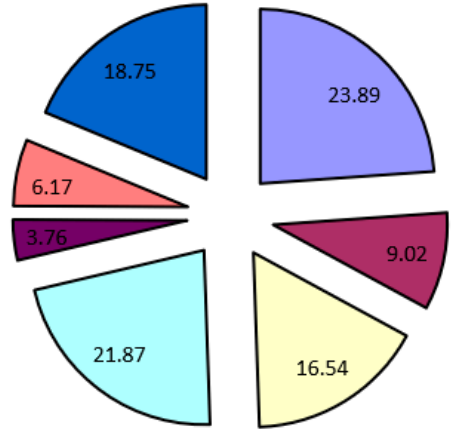

$\begin{array}{ll}\square \text { wheat } & \square \text { barley } \\ \square \text { rapeseed } & \square \text { soybean }\end{array}$

$\square$ corn

$\square$ sunflower

$\square$ others

2018

Figure 8. Structure of the arable land in Ukraine.

There has been a rise in the crop production (Figure 9). The total quantity of crops harvested ranged from 41.51 to 96.45 million tons. Average, minimum, and maximum crop harvests for recent 11 years are presented in Table 4 .

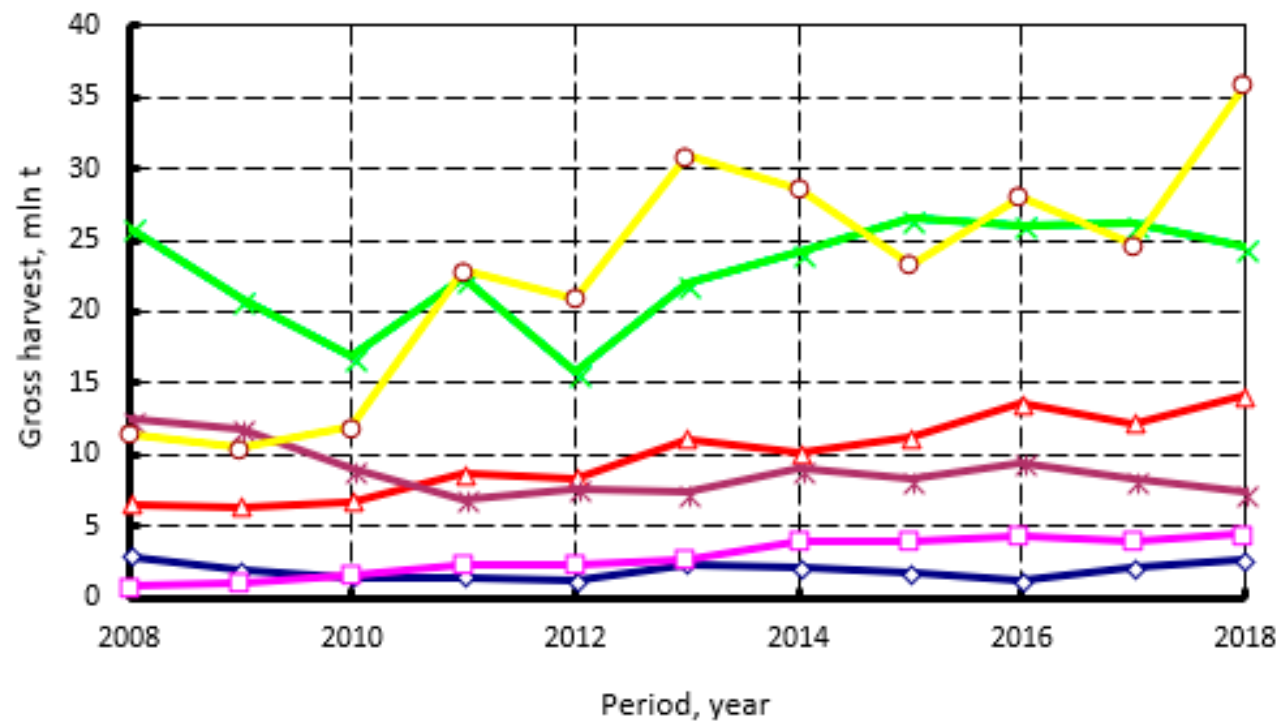

-rapeseed $-\mathrm{Q}$ soybean - sunflower $\longrightarrow$ wheat $m$ barley o corn

Figure 9. Gross crop harvest (adapted from reference [70]).

Table 4. Average, minimum, and maximum crop harvests, in million tons.

\begin{tabular}{llll}
\hline \multicolumn{1}{c}{ Crop } & Average & Minimum & Maximum \\
\hline rapeseed & 1.92 & 1.15 & 2.87 \\
soybean & 2.85 & 0.81 & 4.46 \\
sunflower & 9.92 & 6.36 & 14.17 \\
wheat & 22.83 & 15.76 & 26.53 \\
barley & 8.90 & 6.94 & 12.61 \\
corn & 22.63 & 10.49 & 35.80 \\
Total & 69.04 & 41.51 & 96.45 \\
\hline
\end{tabular}

The residue available for energy production is around 48.66 million tons (Figure 10). This residue is in the following distribution percentages: $19.34 \%$ for wheat straw; $5.32 \%$ for barley straw; $40.46 \%$ for 
corn stalk-; $25.03 \%$ for sunflower stalk-; 3.17\% for rapeseed straw-; $6.67 \%$ for soybean straw. As can be seen, corn stalk, wheat straw, and sunflower residue (stalk and husk) provides around 41.28 million tons or $84.84 \%$ of the total crop residue.

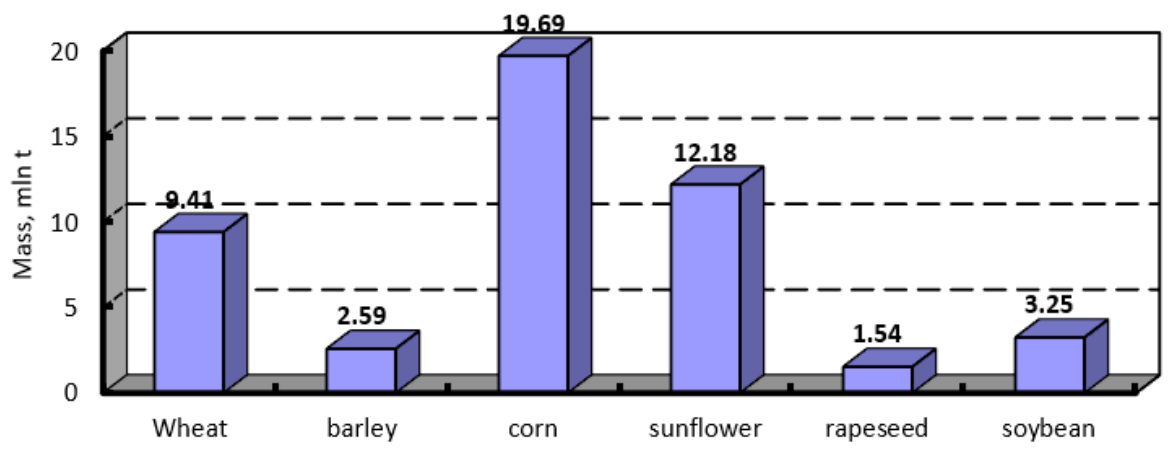

Figure 10. Crop residue available for energy production in 2018.

To evaluate the energy potential, lower heating values of biomass feedstock were used. Properties of the crop residue studied are presented in Table 5.

Table 5. Properties of the crop residue.

\begin{tabular}{|c|c|c|c|c|c|c|c|c|}
\hline Parameter & Unit & $\begin{array}{c}\text { Wheat } \\
\text { Straw [71] }\end{array}$ & $\begin{array}{c}\text { Barley } \\
\text { Straw [71] }\end{array}$ & $\begin{array}{l}\text { Rapeseed } \\
\text { Straw [71] }\end{array}$ & $\begin{array}{c}\text { Soybean } \\
\text { Straw }\end{array}$ & $\begin{array}{c}\text { Corn Stalk } \\
{[72]}\end{array}$ & $\begin{array}{l}\text { Sunflower } \\
\text { Stalk }\end{array}$ & $\begin{array}{l}\text { Sunflower } \\
\text { Husk [73] }\end{array}$ \\
\hline $\begin{array}{l}\text { Lower } \\
\text { heating } \\
\text { value }\end{array}$ & $\mathrm{MJ} / \mathrm{kg}$ & 17.2 & 15.92 & 15.33 & 15.92 & $8-17$ & 16 & 16.5 \\
\hline Bulk density & $\mathrm{kg} / \mathrm{m}^{3}$ & $20-60$ & $54.6-78.3$ & $33-67$ & $27-43$ & $35-80^{*}$ & 112 & 95 \\
\hline Bale density & $\mathrm{kg} / \mathrm{m}^{3}$ & 100-155 & $100-155$ & $100-155$ & $100-155$ & $100-155$ & $100-155$ & - \\
\hline Moisture & $\%$ & 10-20 & 15 & 15 & $7.6-10.9$ & $15-45$ & $20-60$ & 8.4 \\
\hline Ash & $\%$ & $2.6-9.6$ & $2.2-5.9$ & $2.1-7.7$ & $2.6-5.9$ & $3.5-9.0$ & $10-12$ & 2.1 \\
\hline
\end{tabular}

Our study has selected five clusters (Figure 11). Each cluster includes 1 to 9 regions (Table 6). Energy potential for selected clusters (average, minimum energy potential of a certain region of the cluster, and maximum energy potential of a certain region of the cluster) are listed in Table 7 . The Vinnitsa and Poltava regions have the highest energy potential. They totaled 133.48 PJ or 17.23\% of the total country value. The total energy potential is equal to 774.46 PJ. The average energy potential of one region of Ukraine is 32.27 PJ. The energy potential of two clusters (C and D) was lower than the average national value (Table 7). The locations of these clusters are illustrated in Figure 12. 


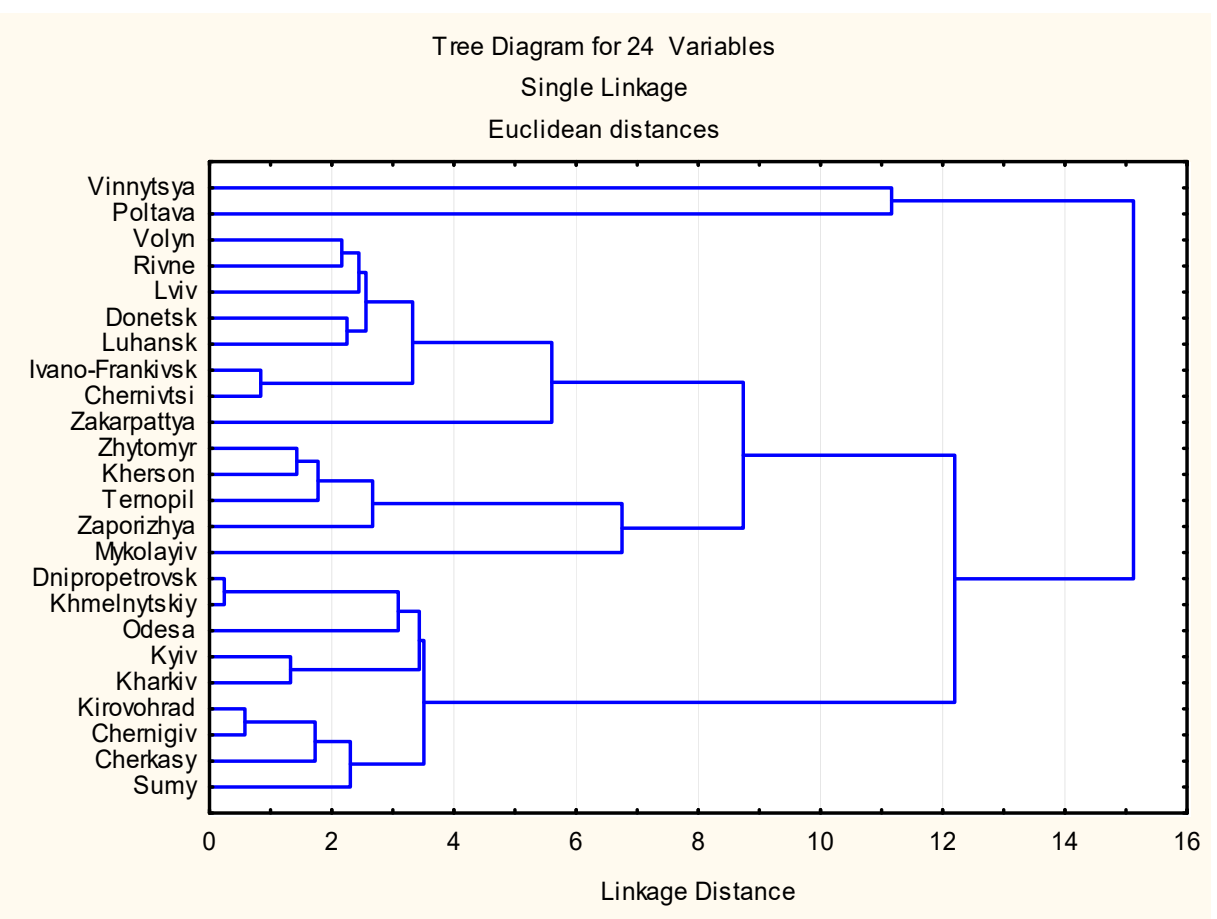

Figure 11. Dendogram of crop residue energy potential.

Table 6. Clusters for residue energy potential.

\begin{tabular}{cccccc}
\hline \multirow{2}{*}{$\mathbf{N r}$} & \multicolumn{5}{c}{ Groups } \\
\cline { 2 - 5 } & A & B & C & D & E \\
\hline 1. & Vinnytsya & Poltava & Volyn & Zhytomyr & Dnipropetrovsk \\
2. & & Rivne & Kherson & Khmelnytskiy \\
3. & & Lviv & Ternopil & Odesa \\
4. & & Donetsk & Zaporizhya & Kyiv \\
5. & & Luhansk & Mykolayiv & Kharkiv \\
6. & & Ivano-Frankivsk & & Kirovograd \\
7. & & Chernivtsi & Chernigiv \\
8. & & Zakarpattya & Cherkasy \\
9. & & & & Sumy \\
\hline
\end{tabular}

Table 7. Average energy potential, PJ.

\begin{tabular}{ccccc}
\hline Group & Average & Sum & $\begin{array}{c}\text { Minimum } \\
\text { (Region) }\end{array}$ & $\begin{array}{c}\text { Maximum } \\
\text { (Region) }\end{array}$ \\
\hline A & 62.79 & 62.79 & 62.79 & 62.79 \\
B & 70.69 & 70.69 & 70.69 & 70.69 \\
C & 10.78 & 86.22 & 3.33 & 16.90 \\
D & 26.70 & 133.49 & 23.08 & 32.00 \\
E & 46.81 & 421.27 & 40.63 & 52.10 \\
Total & 32.27 & 774.46 & 3.33 & 70.69 \\
\hline
\end{tabular}




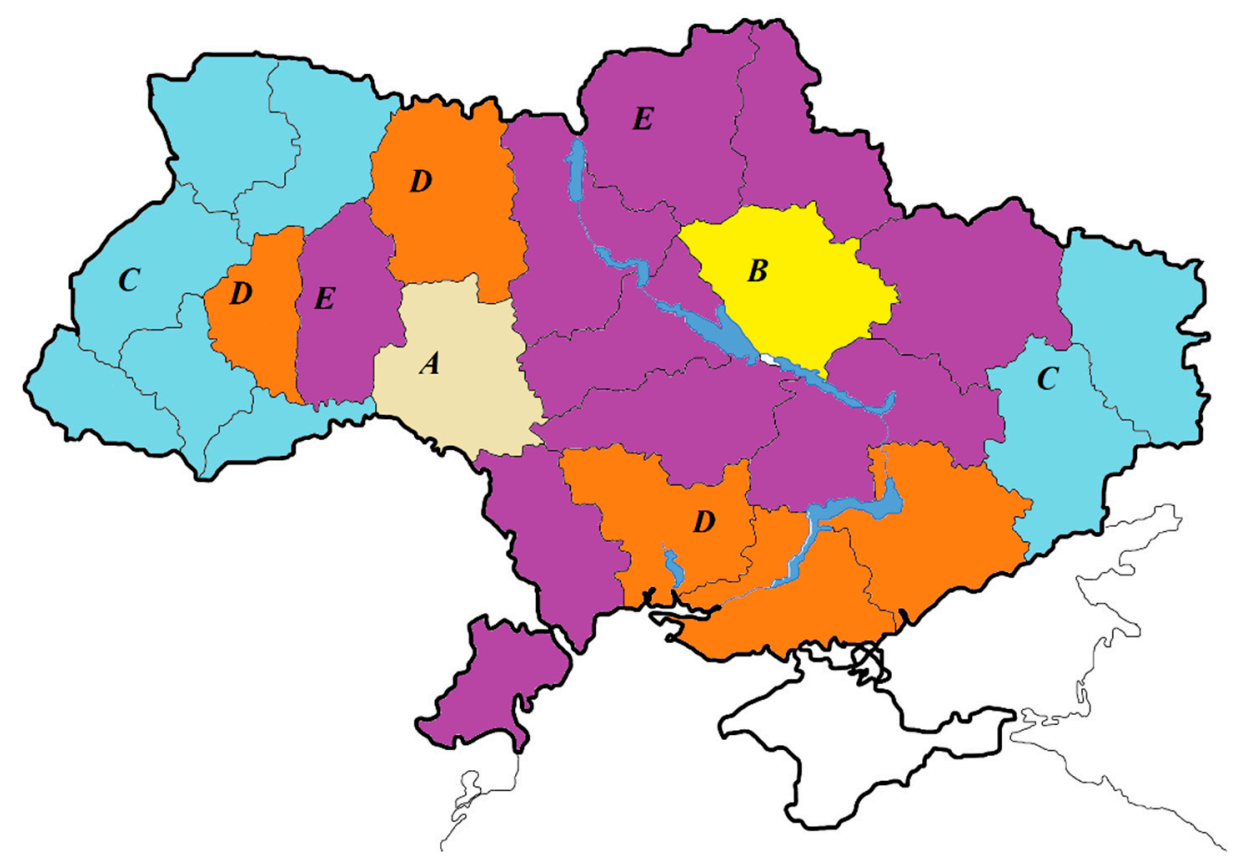

Figure 12. Locations of clusters.

Crop residue is spatially scattered. Therefore, to reduce the transportation cost of biomass feedstock, the locations of power plants have to be optimized. That is why the geographical information of bioenergy feedstock is useful for evaluating the optimal arrangement of new crop residue based power plants. The average national density of energy potential is equal to $13.45 \mathrm{PJ}$ per million hectares. Vinnitsa and Poltava regions have the best results (Figure 13). In these calculations, the official areas of regions were used [74].

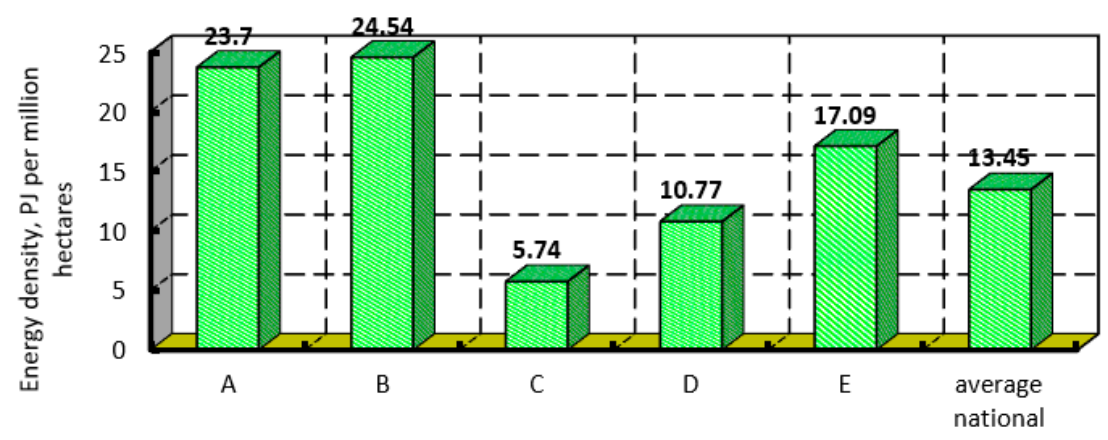

Figure 13. Distribution of the energy potential.

\subsection{Status and Potential Power Generation in Ukraine}

There are about 70 boilers using sunflower husk and straw for heat production. Among biomass power generation plants, there are only a few which use crop residue. These projects use combustion based power and CHP plants. Each plant consists of biomass boilers and a steam turbine for power generation. Their installed power is 12.7 MWe (Table 8). 
Table 8. Crop residue power generation plants.

\begin{tabular}{|c|c|c|c|c|c|}
\hline Name & Region & Feedstock & $\begin{array}{c}\text { Installed } \\
\text { Power, MWe }\end{array}$ & Type & Reference \\
\hline $\begin{array}{l}\text { Kirovogradoil } \\
\text { LLC }\end{array}$ & Kirovograd & Sunflower husk & 1.7 & СHPP & [20] \\
\hline Kargil plant JSC & Donetsk & Sunflower husk & 2.0 & CHPP & [20] \\
\hline Eugroil LLC & Mykolayiv & $\begin{array}{l}\text { Sunflower husk } \\
\text { and wood chip }\end{array}$ & 5.0 & Power plant & [20] \\
\hline Kamyanets-Podilskyi & Khmelnitsk & $\begin{array}{l}\text { Natural gas, straw, } \\
\text { corn stem, } \\
\text { sunflower stalk, } \\
\text { wood chip }\end{array}$ & 4.0 & CHPP & [75] \\
\hline
\end{tabular}

According to our estimation, the electricity generation from agricultural residue has a potential which ranges from 27.75 to 107.99 billion $\mathrm{kWh}$ (Figure 14) or from $17.4 \%$ to $67.8 \%$ of the national generation in 2018. Therefore, the potential of the installed power of crop residue power plants may vary from 4.6 to 18 thousand MW (depending on the technology applied). Ukraine uses less than $0.3 \%$ of available opportunities.

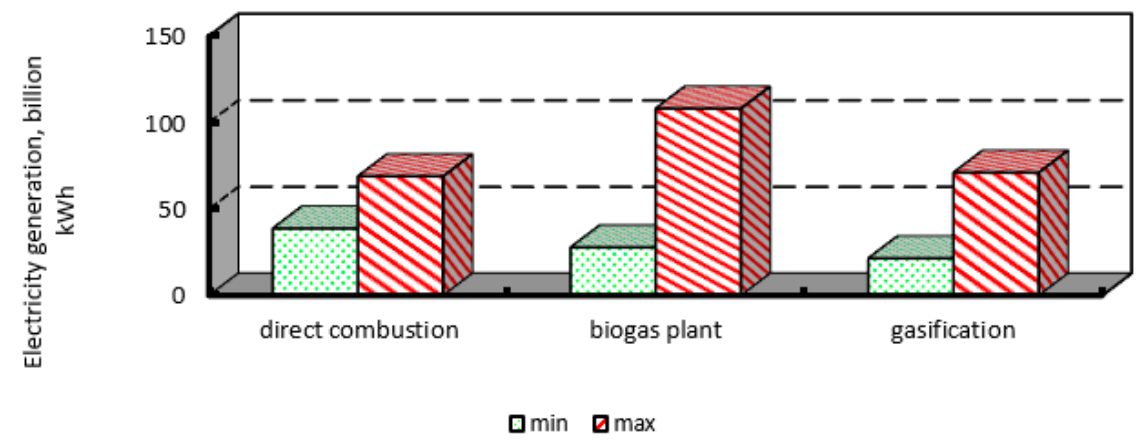

Figure 14. Potential electric generation.

Decentralized crop residue power generation may cover regional electricity requirements. This solution does not substitute for grid electricity, but it is an integral part of the national grid. We then analyzed how a decentralized agro-residue energy solution can meet regional requirements. In our calculations, we assumed that the electric efficiency of combustion based biomass (crop residue) power plants is $30 \%$. This technology was chosen because it is mature and well known in Ukraine. We determined the ratio of potential electricity generation to regional consumption of electricity. The calculations showed that 13 regions (including Vinnitsa and Poltava) can meet their own requirements in electricity by using combustion based biomass (crop residue) power plants (Figure 15). This means biomass power generation technology is promising and should be developed.

The dendrogram of potential self-sufficiency in crop residues for power generation was cut out at 40 (Figure 16). Regions were grouped into five clusters (Table 9) and their group averages, minimum, and maximum (Table 10). 


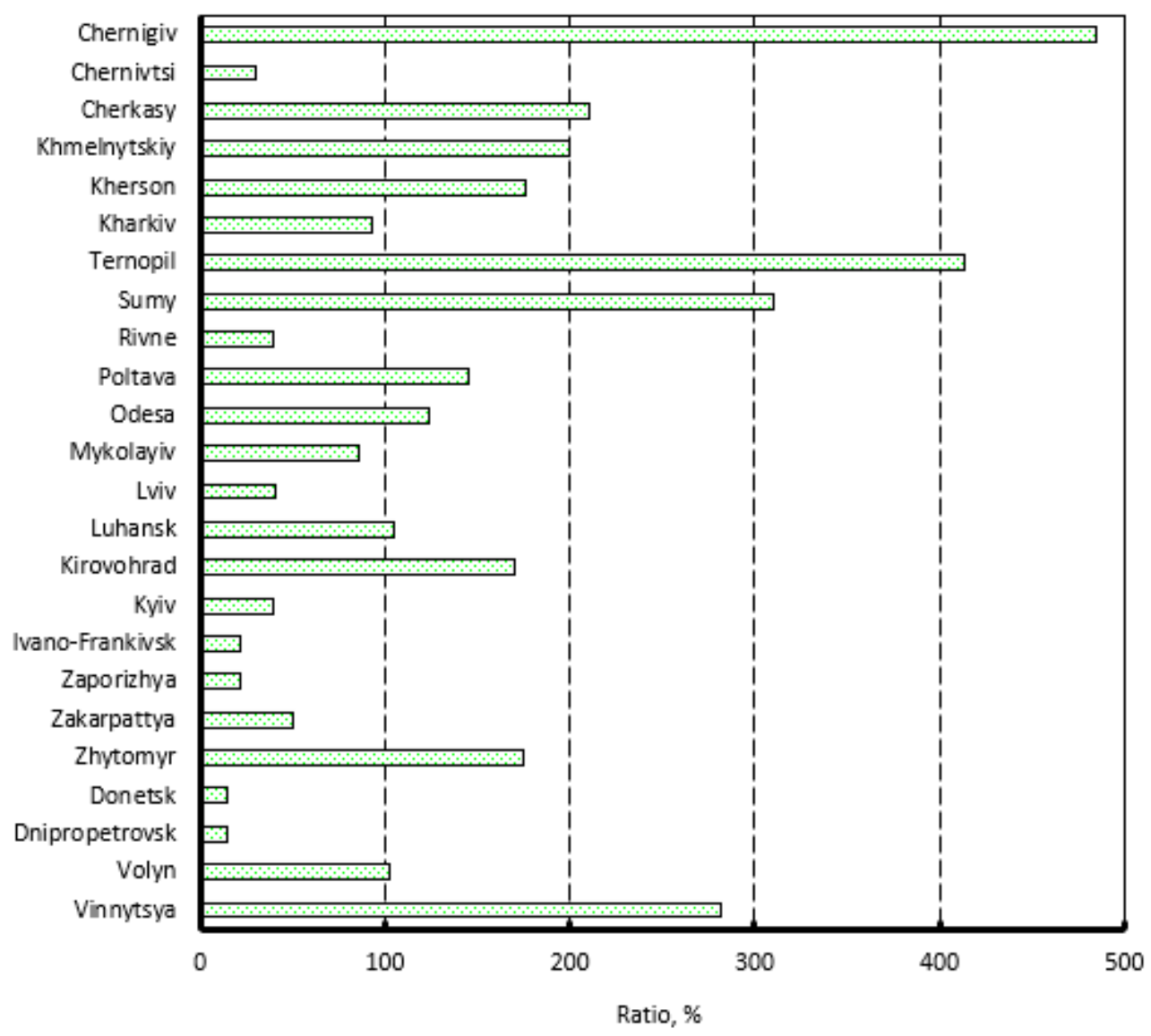

Figure 15. Ratio of potential electricity generation to regional consumption of electricity.

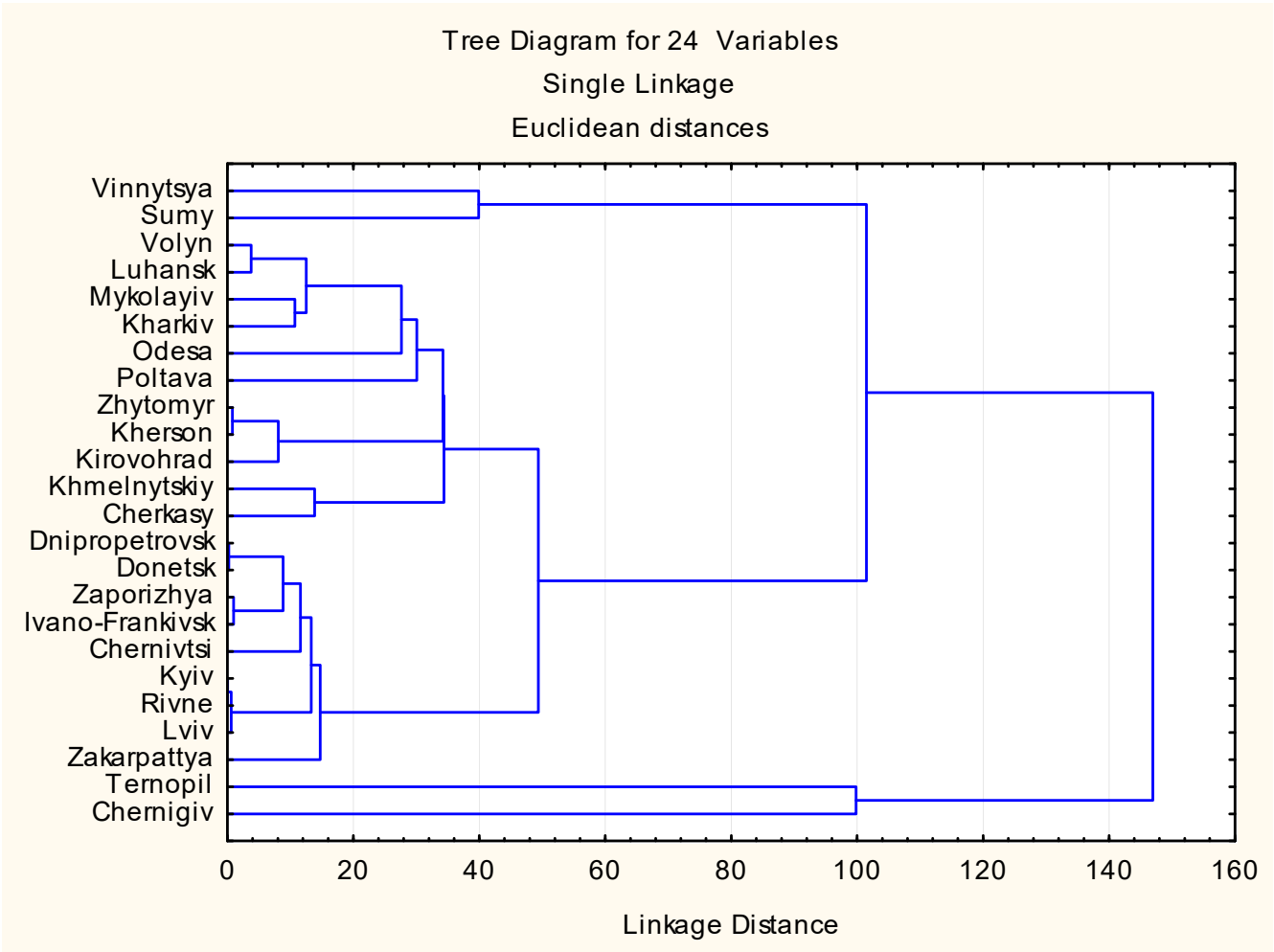

Figure 16. Dendrogram of potential self-sufficiency in crop residues for power generation. 
Table 9. Clusters of self-sufficiency.

\begin{tabular}{ccccc}
\hline \multicolumn{5}{c}{ Groups } \\
\hline B & B & C & D & E \\
\hline Volyn, Luhansk, \\
Mykolayv, Kharkiv, \\
Odesa, Poltava, \\
$\begin{array}{c}\text { Zhytomir, Kherson, } \\
\text { Kirovograd, } \\
\text { Khmelnytskiy, } \\
\text { Cherkasy }\end{array}$ & $\begin{array}{c}\text { Dnepropetrovsk, } \\
\text { Donetsk, } \\
\text { Zaporizhya, } \\
\text { Ivano-Frankivsk, } \\
\text { Chernivtsi, Kyiv, } \\
\text { Rivne, Lviv, } \\
\text { Zakarpattya }\end{array}$ & Ternopil & Chernigiv \\
& & & \\
\end{tabular}

Table 10. Average, minimum, and maximum self-sufficiency, $\%$.

\begin{tabular}{cccc}
\hline Group & Average & Minimum (Region) & Maximum (Region) \\
\hline A & 296.04 & 281.92 & 310.15 \\
B & 144.31 & 102.06 & 210.17 \\
C & 30.53 & 15.21 & 50.70 \\
D & 414.04 & - & - \\
E & 484.63 & - & - \\
\hline
\end{tabular}

Groups D and E consist only of one region. They stand out in comparison with the other groups. The regions of group $\mathrm{C}$ cannot meet their own requirements for electricity using biomass power plants. Six regions (Chernigiv, Cherkasy, Ternopil, Sumy, and Vinnitsa) have more than double the reserves of crop residues needed for power generation. Taking into account the fluctuation of crop harvest (Figure 7 and Table 2), the above regions have minimal risk in the feedstock supply. Therefore, they must prioritize the implementation of biomass power plants.

\section{Conclusions}

Electricity consumption is distributed unevenly in Ukraine. The Dnipropetrovsk, Donetsk, and Kyiv regions consume $44 \%$ of total national electricity production. This poses certain challenges for development of the renewable energy sector in Ukraine.

Ukraine has abundant agricultural crop residue energy resources. Our results showed that the country annually generates up to 128.47 million tons of agricultural crop residues. Indeed, 48.66 million tons of residues may be used for energy production. Corn and sunflower stalks represent $65 \%$ of the total crop residues. In 2018, their energy potential was $774.46 \mathrm{PJ}$, which could be used for power generation.

Using cluster analysis, we identified five groups of regions. The energy potential of Vinnitsa and Poltava regions is $133.8 \mathrm{PJ}$, or $17.2 \%$ of the total national energy potential. They are preferable for setting up crop residue power plants. Regions with high electricity consumption do not have enough crop residue potential to meet their own requirements for electricity.

Power generation potential of crop residues is up to 108 billion $\mathrm{kWh}$. This value is $67.8 \%$ of current national power generation. Thirteen regions have enough crop residues to satisfy their own needs in electricity. Combustion based biomass power plants can generate from 38 to 68 billion $\mathrm{kWh}$ power per annum. To increase electricity generation, methanation technology should be developed.

The results provide a scientific foundation for the development of biomass electricity policy in Ukraine. They may be helpful for creating autonomous power generation zones. The results can support policymakers and investors in their decisions. The advantages of biomass power plants are the following: the reduction of GHG emissions; job creation; strengthening the energy security of Ukraine; the utilization of crop residues; the reduction of fossil fuel consumption; increasing farmers' income. Meanwhile, there are a number of risks [76-78] such as significant harvest fluctuations, which 
may negatively affect the reliability of feedstock supply for electricity generation; increasing biomass feedstock prices; logistics problems. Finding possible solutions is the goal for further research.

Author Contributions: Conceptualization, Y.J.; Formal analysis, V.H. and V.N.; Investigation, Y.J.; Writing—original draft, O.K. and T.B.; Writing—review \& editing, D.S.

Funding: This research received no external funding.

Conflicts of Interest: The authors declare no conflict of interest.

\section{Nomenclature}

$\begin{array}{ll}\text { CHP } & \text { Combined heat and power } \\ E C F & \text { Energy conversion factor } \\ E P & \text { Energy potential [PJ] } \\ \mathrm{GHG} & \text { Greenhouse gas } \\ \mathrm{ICE} & \text { Internal combustion engine } \\ L H V_{D F} & \text { Lower heating value of the derived fuel }\left[\mathrm{MJ} / \mathrm{m}^{3}\right] \\ L H V_{R} & \text { Lower heating value of crop residue }[\mathrm{MJ} / \mathrm{kg}] \\ L H V r_{i} & \text { Lower heating value of } i^{\text {th }} \text { crop residue }[\mathrm{MJ} / \mathrm{kg}] \\ M o_{i} & \text { Harvest weight of } i^{\text {th }} \text { crop [t] } \\ M_{R} & \text { Residue production [t] } \\ \mathrm{ORC} & \text { Organic Rankine Cycle } \\ P P G & \text { Potential power generation }[\text { billion } \mathrm{kWh}] \\ R C P_{i} & \text { Residue to Crop Ratio of } i^{\text {th }} \text { crop } \\ V_{D F} & \text { Volume of derived fuel from crop residue }\left[\mathrm{m}^{3} / \mathrm{kg}\right] \\ \eta_{\mathrm{e}} & \text { The efficiency of power generation }\end{array}$

\section{References}

1. State Enterprise "National Power Company UKRENERGO". Annual Report, 2018. Ministry of Energy and Coal Industry of Ukraine; National Power Company UKRENERGO: Kyiv, Ukraine, 2018. Available online: https: //ua.energy/wp-content/uploads/2019/06/UE_NFR_2018_compressed.pdf (accessed on 12 September 2019).

2. Coal Reserves in Thermal Power Plants in Ukraine $46 \%$ less than Last Year. Business News from Ukraine. Available online: https://open4business.com.ua/coal-reserves-in-thermal-power-plants-in-ukraine-46-lessthan-last-year/ (accessed on 12 September 2019).

3. Maximising the Yield of Biomass from Residue of Agricultural Crops and Biomass from Forestry. Final Report, Project Number: BIENL15082. Ecofys 2016. Available online: https://ec.europa.eu/energy/sites/ener/files/documents/Ecofys\%20-\%20Final_\%20report_\%20EC_ max\%20yield\%20biomass\%20residue\%2020151214.pdf (accessed on 12 September 2019).

4. State Enterprise "National Power Company UKRENERGO". Annual Report, 2014. Ministry of Energy and Coal Industry of Ukraine; National Power Company UKRENERGO: Kyiv, Ukraine, 2014. Available online: https: //ua.energy/wp-content/uploads/2016/12/zvit_ukrenergo_2014WEB.pdf (accessed on 12 September 2019).

5. State Enterprise "National Power Company UKRENERGO". Annual Report, 2013. Ministry of Energy and Coal Industry of Ukraine; National Power Company UKRENERGO: Kyiv, Ukraine, 2013. Available online: https://ua.energy/wp-content/uploads/2016/12/Annual2013_Ukrenergo.pdf (accessed on 12 September 2019).

6. State Enterprise "National Power Company UKRENERGO". Annual Report, 2016. Ministry of Energy and Coal Industry of Ukraine; National Power Company UKRENERGO: Kyiv, Ukraine, 2016. Available online: https://ua.energy/wp-content/uploads/2018/02/Annual-report_2016.pdf (accessed on 12 September 2019).

7. Cramer, J.; Wissema, E.; de Bruijne, M.; Lammers, E.; Dijk, D.; Jager, H.; van Bennekom, S.; Breunesse, E.; Horster, R.; van Leenders, C. Testing Framework for Sustainable Biomass: Final Report from the Project Group "Sustainable Production of Biomass"; Energy Transition's Interdepartmental Programme Management (IPM): Utrecht, The Netherlands, 2007; Available online: https:/library.wur.nl/WebQuery/groenekennis/1975871 (accessed on 12 September 2019).

8. Gustavsson, L.; Holmberg, J.; Dornburg, V.; Sathre, R.; Eggers, T.; Mahapatra, K.; Marland, G. Using biomass for climate change mitigation and oil use reduction. Energy Policy 2007, 35, 5671-5691. [CrossRef] 
9. European Union (EU). Directive (EU) 2015/1513 of the European Parliament and of the Council of 9 September 2015 Amending Directive 98/70/EC Relating to the Quality of Petrol and Diesel Fuels and Amending Directive 2009/28/EC on the Promotion of the Use of Energy from Renewable Sources; European Union: Brussels, Belgium, 2015.

10. He, G.; Bluemling, B.; Mol, A.P.J.; Zhang, L.; Lu, Y. Comparing centralized and decentralized bio-energy systems in rural China. Energy Policy 2013, 63, 34-43. [CrossRef]

11. Li, Q.; Hu, S.; Chen, D.; Zhu, B. System analysis of grain straw for centralized industrial usages in China. Biomass Bioenergy 2012, 47, 277-288. [CrossRef]

12. Gao, J.; Zhang, A.; Lam, S.K.; Zhang, X.; Thomson, A.M.; Lin, E.; Jiang, K.; Clarke, L.E.; Edmonds, J.A.; Kyle, P.G.; et al. An integrated assessment of the potential of agricultural and forestry residues for energy production in China. United States. GCB Bioenergy 2016, 8, 880-893. [CrossRef]

13. Bentsen, N.S.; Felby, C.; Thorsen, B.J. Agricultural residue production and potentials for energy and materials services. Prog. Energy Combust. Sci. 2014, 40, 59-73. [CrossRef]

14. Ren, J.; Yu, P.; Xu, X. Straw Utilization in China-Status and Recommendations. Sustainability 2019, 11, 1762. [CrossRef]

15. Garcia, D.A.; Sangiorgio, S.; Rosa, F. Estimating the potential biomasses energy source of forest and agricultural residue in the Cinque Terre Italian National Park. Energy Procedia 2015, 82, 674-680. [CrossRef]

16. Griffin, W.M.; Michalek, J.; Matthews, H.S.; Hassan, M.N.A. Availability of Biomass Residue for Co-Firing in Peninsular Malaysia: Implications for Cost and GHG Emissions in the Electricity Sector. Energies 2014, 7, 804-823. [CrossRef]

17. García, C.; Montero, G.; Coronado, M.; Torres, R.; Vázquez, A.M.; Ayala, J.R.; León, J.A.; Sagaste, C.A. Power generation estimation from wheat straw in Mexico. Energy Sustain. VI WIT Trans. Ecol. Environ. 2015, 195, 101-110. [CrossRef]

18. Jeguirim, M.; Limousy, L. Strategies for bioenergy production from agriculture and agrifood processing residues. Biofuels 2018, 9, 541-543. [CrossRef]

19. Muradin, M.; Joachimiak-Lechman, K.; Foltynowicz, Z. Evaluation of Eco-Efficiency of Two Alternative Agricultural Biogas Plants. Appl. Sci. 2018, 8, 2083. [CrossRef]

20. Geletukha, G.G.; Zheliezna, T.A.; Bashtovyi, A.I. Energy and ecology analysis of technologies for power production from biomass. Part 1. Ind. Heat Eng. 2017, 39, 58-64. [CrossRef]

21. Fedorchenko, B.S. Cluster Analysis of Bioenergetic Potential in Regions of Ukraine. Account. Financ. 2014, 64, 173-178. Available online: http://irbis-nbuv.gov.ua/cgi-bin/irbis_nbuv/cgiirbis_64.exe?C21COM= 2\&I21DBN=UJRN\&P21DBN=UJRN\&IMAGE_FILE_DOWNLOAD=1\&Image_file_name=PDF/Oif_apk_ 2014_2_27.pdf (accessed on 18 September 2019).

22. Melnychenko, V. Cluster modeling of bioenergy potential of agricultural enterprises. Econ. State 2018, 2, 124-128. Available online: http://Economy.in.ua/pdf/2_2018/28.pdf (accessed on 12 September 2019).

23. Zvorykin, A.; Pioro, I.; Fialko, N. Electricity generation in the world and Ukraine: Current status and future developments. Mech. Adv. Technol. 2017, 2, 5-24. [CrossRef]

24. Geletukha, G.; Oliinyk, Y.; Zheliezna, T. Prospects for the Electricity Generation from Biomass in Ukraine. UABio Position Paper, 5, 2013. Available online: http://www.uabio.org/img/files/docs/position-paper-uabio-5-en.pdf (accessed on 12 September 2019).

25. Atamanyuk, I.P. Algorithm of extrapolation of a nonlinear random process on the basis of its canonical decomposition. Cybern. Syst. Anal. 2005, 41, 267-273. [CrossRef]

26. Kondratenko, Y.P.; Kozlov, O.V.; Kondratenko, G.V.; Atamanyuk, I.P. Mathematical Model and Parametrical Identification of Ecopyrogenesis Plant Based on Soft Computing Techniques. Complex Syst. Solut. Chall. Econ. Manag. Eng. 2018, 125, 201-233. [CrossRef]

27. Meyer, A.K.P.; Ehimen, E.A. Future European biogas: Animal manure, straw and grass potentials for a sustainable European biogas production. Biomass Bioenergy 2018, 111, 154-164. [CrossRef]

28. Lantz, M.; Prade, T.; Ahlgren, S.; Björnsson, L. Biogas and Ethanol from Wheat Grain or Straw: Is There a Trade-Off between Climate Impact, Avoidance of iLUC and Production Cost? Energies 2018, 11, 2633. [CrossRef]

29. Sunde, K.; Brekke, A.; Solberg, B. Environmental Impacts and Costs of Woody Biomass-to-Liquid (BTL) Production and Use-A Review. For. Policy Econ. 2011, 13, 591-602. [CrossRef]

30. Liu, H.; Ou, X.; Yuan, J.; Yan, X. Experience of producing natural gas from corn straw in China. Resour. Conserv. Recycl. 2018, 135, 216-224. [CrossRef] 
31. Biomass for Heat and Power Technology Brief. IEA-ETSAP and IRENA Technology Brief E05, 2015. Available online: https://biomasspower.gov.in/document/Reports/IRENA_Biomass\%20for\%20Heat\%20and\%20Power.pdf (accessed on 12 September 2019).

32. Hansen, M.T. Biomass based Combined Heat and Power Generation. 2014. Available online: http: //www.videncenter.dk/exportcat/combined_heat_and_power.pdf (accessed on 12 September 2019).

33. Zhang, Z.; Zhao, W.; Zhao, W. Commercialization Development of Crop Straw Gasification Technologies in China. Sustainability 2014, 6, 9159-9178. [CrossRef]

34. Ataei, A.; Azimi, A.; Kalhori, S.B.; Abari, M.F.; Radnezhad, H. Performance analysis of a co-gasifier for organic waste in agriculture. Int. J. Recycl. Org. Waste Agric. 2012, 1. [CrossRef]

35. Complete Power Generating System Solutions. Ettes Power, 2016. Available online: http://www.ettespower.com/uploadfile/fckeditor/images/file/2016/10\%E6\%9C\%88/\%E6\%B7\%84\%E6\% 9F\%B4pdf\%E5\%8A\%A0\%E5\%AF\%86/Main\%20Technical\%20Datasheet\%20of\%20300kW\%20Biomass \% 20Generating\%20Set-Ettes\%20Power.pdf (accessed on 12 September 2019).

36. Obernberger, I.; Thek, G. Cost assessment of selected decentralized CHP applications based on biomass combustion and biomass gasification. In Proceedings of the 16th European Biomass Conference Exhibition, Valencia, Spain, 2-6 June 2008; Valencia, ETA-Renewable Energies: Florence, Italy, 2008. Available online: https://bios-bioenergy.at/uploads/media/Paper-Obernberger-Cost-assessment-CHP-BM-comustiongasification-2008-05-30.pdf (accessed on 12 September 2019).

37. Power Generator Solutions. Steel Head Metal Fab. LLC. 2014. Available online: http://www.steelheadmetals. com/docs/catalog/2014/Steelhead_GeneratorCatalog_web.pdf (accessed on 12 September 2019).

38. Ruiz, J.A.; Juárez, M.C.; Morales, M.P.; López-Ochoa, L.M.; Doménech, J. Biomass gasification or combustion for generating electricity in Spain: Review of its current situation according to the opinion of specialists in the field. J. Renew. Sustain. Energy 2013, 5, 012801. [CrossRef]

39. Perkins, G.; Bhaskar, T.; Konarova, M. Process development status of fast pyrolysis technologies for the manufacture of renewable transport fuels from biomass. Renew. Sustain. Energy Rev. 2018, 90, 292-315. [CrossRef]

40. Benato, A.; Macor, A. Biogas Engine Waste Heat Recovery Using Organic Rankine Cycle. Energies 2017, 10, 327. [CrossRef]

41. Jenbacher J920 Flextra Gas Engine. KST Engineering. Available online: https://kts-eng.com/en/equipment/ gas-engines/type-9/jenbacher-j920-flextra/ (accessed on 12 September 2019).

42. Dolz, V.; Novella, R.; García, A.; Sánchez, J. HD Diesel engine equipped with a bottoming Rankine cycle as a waste heat recovery system. Part 1: Study and analysis of the waste heat energy. Appl. Therm. Eng. 2012, 36, 269-278. [CrossRef]

43. Braun, R.; Weiland, P.; Wellinger, A. Biogas from Energy Crop Digestion. Task 37-Energy from Biogas and Landfill Gas. IEA Bioenergy, 2010. Available online: http://rembio.org.mx/wp-content/uploads/2015/01/ Braun_BiogasFromEnergyCropDigestion.pdf (accessed on 12 September 2019).

44. Sukhesh, M.J.; Rao, P.V. Anaerobic digestion of crop residue: Technological developments and environmental impact in the Indian context. Biocatal. Agric. Biotechnol. 2018, 16, 513-528. [CrossRef]

45. Fu, Y.; Luo, T.; Mei, Z.; Li, J.; Qiu, K.; Ge, Y. Dry Anaerobic Digestion Technologies for Agricultural Straw and Acceptability in China. Sustainability 2018, 10, 4588. [CrossRef]

46. Hong, L.; Zhou, N.; Fridley, D.; Raczkowski, C. Assessment of China's renewable energy contribution during the 12th Five Year Plan. Energy Policy 2013, 62, 1533-1543. [CrossRef]

47. Sherrard, A. Breaking the Straw to Biogas Conundrum. 2016. Available online: https://bioenergyinternational. $\mathrm{com} /$ feedstock/breaking-the-straw-to-biogas-conundrum (accessed on 12 September 2019).

48. First-of-its-Kind Rice Straw to Biogas Facility Launched in the Philippines. 2019. Available online: https://bioenergyinternational.com/biogas/launch-of-rice-straw-biogas-facility-in-the-philippines (accessed on 12 September 2019).

49. Verbio Commissions Straw-to-Biogas Facility in Germany. 2015. Available online: http:// biomassmagazine.com/articles/11866/verbio-commissions-straw-to-biogas-facility-in-germany (accessed on 12 September 2019).

50. Chandra, R.; Vijay, V.K.; Subbarao, P.M.V.; Nagpal, S.; Trivedi, A.; Jha, B.; Vijay, V. Paddy straw-based power generation from biogas Fazilka. District in Punjab Leading the Way! Energy Future 2106, 4, 52-56. 
51. Quoilin, S.; Broek, M.V.D.; Declaye, S.; Dewallef, P.; Lemort, V. Techno-economic survey of Organic Rankine Cycle (ORC) systems. Renew. Sustain. Energy Rev. 2013, 22, 168-186. [CrossRef]

52. Canergy Selects Chemtex and Beta Renewables for Its Cellulosic Ethanol Project in California 2013. Available online: http://www.prweb.com/releases/2013/4/prweb10685439.htm (accessed on 12 September 2019).

53. Scarlat, N.; Dallemand, J.-F.; Fahl, F. Biogas: Developments and perspectives in Europe. Renewable Energy 2018, 129, 457-472. [CrossRef]

54. First Phase of EUR $11 \mathrm{mln}$ Biogas Plant Commissioned in Vinnytsya Region. Latifundist. Available online: https://atifundist.com/en/novosti/47492-na-vinnichchine-zapustili-biogazovyj-kompleks-za-11-mln (accessed on 27 October 2019).

55. Finnish Company to Build Biogas Plant in Ukraine. Investment and Finance News in Ukraine. Available online: https://inventure.com.ua/en/news/ukraine/finnish-company-to-build-biogas-plant-inukraine (accessed on 26 November 2019).

56. European Technology and Innovation Platform Bioenergy (ETIPB). Cellulosic Ethanol 2017. Available online: http://www.etipbioenergy.eu/?option=com_content\&view=article\&id=273\#ce1 (accessed on 12 September 2019).

57. The Straw Ethanol Factory. Available online: http://www.sbe.fi/SBEeng/Factory.html (accessed on 12 September 2019).

58. Crescentino Biorefinery-PROESA, Italy. Available online: http://www.ieabioenergy.com/wp-content/ uploads/2018/02/3-Crescentino-AdvancedEthanolBiorefinery_IT_Final.pdf (accessed on 12 September 2019).

59. India's First Cellulosic Alcohol Technology Demonstration Plant to be Inaugurated in Kashipur, Uttrakhand. Available online: http://birac.nic.in/webcontent/Curtain_raise_19_04_2016.pdf (accessed on 12 September 2019).

60. GranBio Cellulosic Ethanol Production Project, Alagoas 2014. Available online: https://www.chemicalstechnology.com/projects/graalbio-cellulosic-ethanol-project-brazil/ (accessed on 12 September 2019).

61. Wheat Straw to Ethanol Conversion Plant Opens in Germany 2012. Available online: http://www.ensnewswire.com/ens/jul2012/2012-07-26-01.html (accessed on 12 September 2019).

62. Verbio Ethanol Zörbig GmbH Co. KG. Available online: https://www.verbio.de/en/group/corporate-structure/ verbio-ethanol-zoerbig/ (accessed on 12 September 2019).

63. Longlive Bio-Technology to Further Expand Production of Cellulosic Ethanol 2014. Available online: http://eshare.cnchemicals.com/publishing/home/2014/09/03/1695/longlive-bio-technology-to-furtherexpand-production-of-cellulosic-ethanol.html (accessed on 12 September 2019).

64. Scarlat, N.; Martinov, M.; Dallemand, J.-F. Assessment of the availability of agricultural crop residue in the European Union: Potential and limitations for bioenergy use. Waste Manag. 2010, 30, 1889-1897. [CrossRef]

65. Cardoen, D.; Joshi, P.; Diels, L.; Sarma, P.M.; Pant, D. Agriculture biomass in India: Part 1. Estimation and characterization. Resour. Conserv. Recycl. 2015, 102, 39-48. [CrossRef]

66. Geletukha, G.; Zheliezna, T. Prospects for the Use of Agricultural Residue for Energy Production in Ukraine. UABio Position Paper, 7. Available online: http://www.uabio.org/img/files/docs/Position-paper-UABIO-7EN.pdf (accessed on 12 September 2019).

67. Monforti, F.; Bódis, K.; Scarlat, N.; Dallemand, J.-F. The Possible Contribution of Agricultural Crop Residue to Renewable Energy Targets in Europe: A Spatially Explicit Study. Renew. Sustain. Energy Rev. 2013, 19, 666-677. [CrossRef]

68. Weiser, C.; Zeller, V.; Reinicke, F.; Wagner, B.; Majer, S.; Vetter, A.; Thraen, D. Integrated assessment of sustainable cereal straw potential and different straw-based energy applications in Germany. Appl. Energy 2014, 114, 749-762. [CrossRef]

69. De Noord, M.; Beurskens, L.W.M.; De Vries, H.J. Potentials and Costs for Renewable Electricity Production. A data Overview 2004. ECN-C 03-006. Available online: https://www.bjmgerard.nl/wp-content/ uploads/2015/03/potentials-and-costs-for-renewable-electricity-production_ECN_feb2004.pdf (accessed on 12 September 2019).

70. State Statistics Service of Ukraine. Crop Production of Ukraine. Statistical Yearbook, 2018. Available online: http://www.ukrstat.gov.ua/druk/publicat/kat_u/2019/zb/04/zb_rosl_2018.pdf (accessed on 12 September 2019).

71. Adapa, P.; Tabil, L.; Schoenau, G. Grinding performance and physical properties of non-treated and steam-exploded barley, canola, oat, and wheat straw. Biomass Bioenergy 2011, 35, 549-561. [CrossRef] 
72. Physico-Mechanical Properties of Corn. Available online: http://razvitie-pu.ru/?page_id=6629 (accessed on 12 September 2019).

73. Perea-Moreno, M.-A.; Manzano-Agugliaro, F.; Perea-Moreno, A.-J. Sustainable Energy Based on Sunflower Seed Husk Boiler for Residential Buildings. Sustainability 2018, 10, 3407. [CrossRef]

74. Rating of Ukrainian Regions by Area of their Territories. 2016. Available online: http://blog.suspilneoko.org. ua/plosha-oblastey/ (accessed on 12 September 2019).

75. Kamyanets-Podilsky Biomass Power Plant. Available online: https://teslaenergo.com/ (accessed on 12 September 2019).

76. Karasoy, A.; Akcay, S. Effects of renewable energy consumption and trade on environmental pollution: The Turkish case. Manag. Environ. Qual. Int. J. 2019, 30,437-455. [CrossRef]

77. Zhao, Q.; Chen, Q.; Xiao, Y.; Tian, G.; Chu, X.; Liu, Q. Saving forests through development? Fuelwood consumption and the energy-ladder hypothesis in rural Southern China. Transform. Bus. Econ. 2017, 16, 199-219.

78. Wang, Q.; Gao, Z.; Yuan, X.; Wang, J.; Wang, M. Comprehensive emergy evaluation and optimization of corn straw power generation system: A case study. Chin. J. Popul. Resour. Environ. 2019, 17, 135-144. [CrossRef]

(C) 2019 by the authors. Licensee MDPI, Basel, Switzerland. This article is an open access article distributed under the terms and conditions of the Creative Commons Attribution (CC BY) license (http://creativecommons.org/licenses/by/4.0/). 